\title{
Persistence of a Reintroduced Fisher, Martes pennanti, Population in Cooking Lake-Blackfoot Provincial Recreation Area, Central Alberta
}

\author{
Gilbert ProulX and Brian Genereux
}

Alpha Wildlife Research \& Management Ltd., 229 Lilac Terrace, Sherwood Park, Alberta T8H 1W3 Canada

Proulx, Gilbert, and Brian Genereux. 2009. Persistence of a reintroduced Fisher, Martes pennanti, population in Cooking Lake-Blackfoot Provincial Recreation Area, central Alberta. Canadian Field-Naturalist 123(2): 178-181.

In order to confirm the persistence of a Fisher (Martes pennanti) population reintroduced in 1990 in Cooking LakeBlackfoot Provincial Recreation Area, central Alberta, we inventoried trails in the winters of 2006 and 2007. We recorded the presence of Fishers in 16 locations, and we confirmed the presence of at least two animals. We believe that the presence of Fishers 17 years after their release in the recreation area indicates that there is a self-sustaining population.

Key Words: Fisher, Martes pennanti, Parklands, reintroduction, Alberta.

Habitat loss, unregulated trapping, and predator control significantly reduced or eliminated Fisher (Martes pennanti) populations in south-central Alberta by the mid-1980s (Douglas and Strickland 1987; Alberta Fish and Wildlife Division 1989*). In an effort to reestablish Fisher populations in the central parklands of Alberta, Proulx et al. (1994) reintroduced 20 Fishers in 1990 and monitored them using radio-telemetry until 1992 (Badry et al. 1997). The success of a reintroduction program should be measured not only by the successful release of individuals but also by the ability of those animals to reproduce successfully and create a self-sustaining population post-reintroduction. Some authors suggest that a reintroduced population should persist for 10 years for the program to be termed a success (Hayward et al. 2007; Muths and Dreitz 2008). In the early 1990s, the reintroduced Fishers settled in the vicinity of their release sites (Proulx et al. 1994) and reproduced (Proulx et al. 2004). However, no inventory occurred in the release area since 1993 to confirm the persistence of the reintroduced Fisher population. The objective of this study was to document the winter distribution of Fishers in the Cooking Lake-Blackfoot Provincial Recreation Area in central Alberta.

\section{Study Area and Methods}

The Cooking Lake-Blackfoot Provincial Recreation Area $\left(53^{\circ} 32^{\prime} \mathrm{N}, 112^{\circ} 47^{\prime} \mathrm{W}\right)$ is a $97 \mathrm{~km}^{2}$ natural area located south of Elk Island National Park, approximately $40 \mathrm{~km}$ east of the city of Edmonton, Alberta (Figure 1). The region is part of the central parklands that consist of open grassland alternating with groves. The groves were composed of mainly Quaking Aspen (Populus tremuloides) with Balsam Poplar (Populus balsamifera), willows (Salix spp.), Paper Birch (Betula papyrifera), and White Spruce (Picea glauca) (Hardy Associates Ltd. 1986*; Looman and Best 1987).

In the winters of 2006 and 2007 from January to March 2006 and November 2006 to February 2007 we repeatedly inventoried 20 trails by snowshoe (a total of $136 \mathrm{~km}$ over two years) that crossed areas where the Fishers had been released in the 1990s. We recorded only well-defined tracks, those not melted or deformed, and not filled with snow. We used the combination of footprint (pattern and size, presence/absence of toe pad prints) and trail (gait, distance between jumps, and dragging of the feet) characteristics to identify all tracks (Murie 1975; Rezendes 1992; Halfpenny et al. 1995). Fishers' foot pads have sparse hair, and they show well in clear prints (Halfpenny et al. 1995). Fishers tend to create a trough when walking in soft snow, drag their feet, and leave tail drag-marks in the snow (de Vos 1951; Raine 1983).

\section{Results and Discussion}

Fisher tracks were recorded at 16 locations along trails (Figures 1 and 2). We were not able to determine whether tracks found during different inventories within the same portion of the study area belonged to the same animal because home ranges may overlap (Badry et al. 1997; Weir 2003*) and winter dispersal movements are known to occur (Arthur et al. 1993). On the other hand, under ideal snow conditions on the same day, we were able to identify two different series of Fisher tracks that were $2 \mathrm{~km}$ apart: one with 5 -cmwide tracks, and another with $\geq 6.5$-cm-wide tracks. Fishers appeared to use the north-central portion of the study area. All tracks were found in deciduous forests, as has been reported by Badry et al. (1997).

This study confirmed the presence of Fishers 17 years after their release in the study area. The Fisher population in the Cooking Lake-Blackfoot Provincial Recreation Area is well removed ( $>150 \mathrm{~km}$ ) from Fisher populations inhabiting boreal forests (Figure 1; Proulx et al. 2004), and immigration is very unlikely (Badry et al. 1997). The area is surrounded by agricultural fields, and the survival of animals dispersing from northern forests through open fields would be low (Proulx et al. 1994). In the last 17 years, Fisher sightings and signs have been reported in the vicinity of the Cooking Lake-Blackfoot Provincial Recreation Area (Dekker 2005; Proulx, unpublished data). A young Fisher was captured in a Beaver (Castor canadensis) trap within the recreation area in 1993. This study confirmed the presence of Fishers in habitats where animals had been released in the early 1990s. All this 


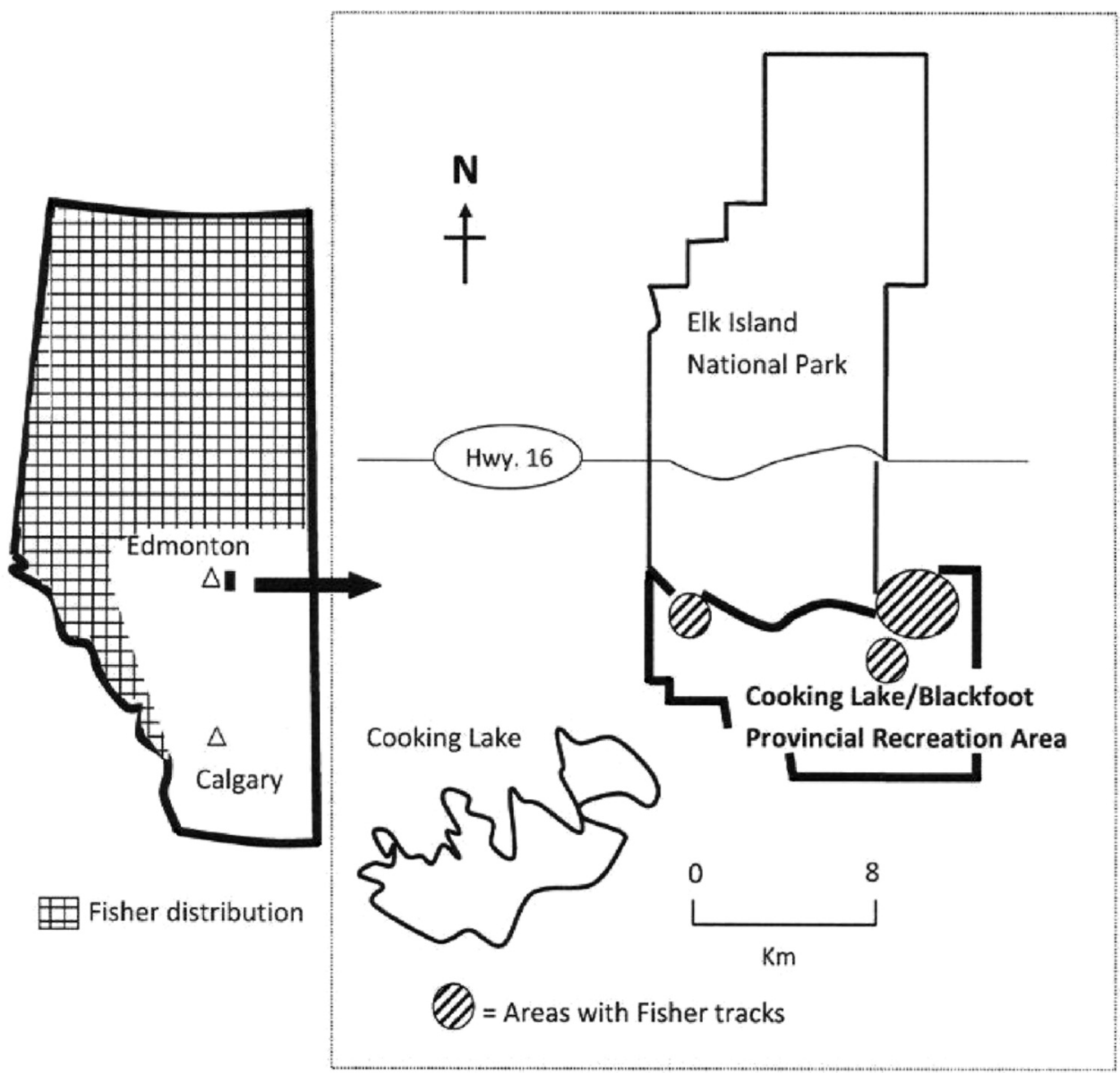

FIGURE 1. Distribution of Fisher in Alberta (after Proulx et al. 2004) and in Cooking Lake-Blackfoot Provincial Recreation Area, winters of 2006 and 2007.

evidence leads us to believe that the presence of Fishers in the Cooking Lake-Blackfoot Provincial Recreation Area is the result of reproduction, which suggests that the population is self-sustaining.

\section{Acknowledgments}

We thank the Alberta Conservation Association for funding this project. We thank Pauline Feldstein from Alpha Wildlife Research \& Management for reading an earlier version of the manuscript. Two anonymous reviewers provided helpful comments.

Documents Cited (marked $*$ in text)

Alberta Fish \& Wildlife Division. 1989. Trapping regulations. Government of Alberta. Booklet, Edmonton, Alberta.

Hardy Associates, Ltd. 1986. Ecological land classification of Elk Island National Park. Report prepared for Parks Canada, Calgary, Alberta, Canada.
Weir, R. D. 2003. Status of fishers in British Columbia. British Columbia Ministry of Sustainable Resource Management, Conservation Data Centre, and Ministry of Water, Land and Air Protection, Biodiversity Branch. Wildlife Bulletin No. B-105, Victoria, British Columbia.

\section{Literature Cited}

Arthur, S. M., T. F. Paragi, and W. B. Krohn. 1993. Dispersal of juvenile fisher in Maine. Journal of Wildlife Management 57: 868-874

Badry, M. J., G. Proulx, and P. M. Woodard. 1997. Habitat use by fishers in the aspen parkland of Alberta. Pages 233-251 in Martes: taxonomy, ecology, techniques and management. Edited by G. Proulx, H. N. Bryant, and P. M. Woodard. Provincial Museum of Alberta, Edmonton, Alberta, Canada.

Dekker, D. 2005. The elusive Fisher. Edmonton NatureNews 2 (1): $19-20$.

de Vos, A. 1951. Tracking of fisher and marten. Sylva 7: 1519. 


\section{2 (a)}
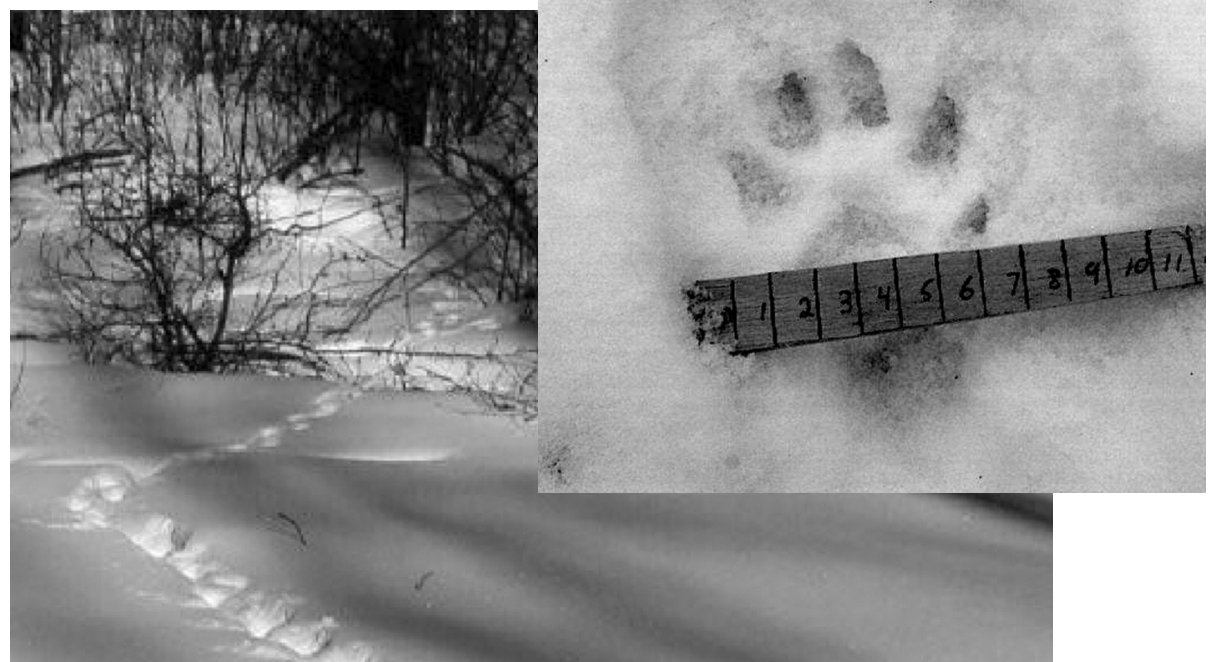

\section{2 (b)}

FIGURE 2. Fisher tracks recorded in Cooking Lake-Blackfoot Provincial Recreation Area: (a) footprint, and (b) 2-2 running pattern. 
Douglas, C. W., and M. A. Strickland. 1987. Fisher. Pages 511-529 in Wild furbearer management and conservation in North America. Edited by M. Novak, J. A. Baker, M. E. Obbard, and B. Malloch. Ontario Trappers Association, North Bay, Ontario, Canada.

Halfpenny J. C., R. W. Thompson, S. C. Morse, T. Holden, and P. Rezendes. 1995. Snow tracking. Pages 91-163 in American marten, fisher, lynx and wolverine: survey methods for their detection. Edited by W. J. Zielinski and T . Kucera. U.S. Department of Agriculture, Forest Service, Pacific Southwest Research Station General Technical Report PSW-GTR-157.

Hayward, M. W., J. Adendorff, J. O'Brien, A. SholtoDouglas, C. Bissett, L. C. Moolman, P. Bean, A. Fogarty, D. Howarth, R. Slater, and G. I. H. Kerley. 2007. The reintroduction of large carnivores to the Eastern Cape, South Africa: an assessment. Oryx 41: 205-214.

Looman, F., and K. F. Best. 1987. Budd's flora of the Canadian prairie provinces. Research Branch, Agriculture Canada, Publication 1662, Minister of Supply and Services Canada, Hull, Quebec, Canada.

Murie, O. J. 1975. A field guide to animal tracks. The Peterson's field guide series. Houghton Mifflin Co., Boston, Massachusetts, USA.

Muths, E., and V. Dreitz. 2008. Monitoring programs to assess reintroduction efforts: a critical component in recovery. Animal Biodiversity and Conservation 31: 47-56.
Proulx, G. 2005. The Fisher of our Aspen Parklands. Edmonton NatureNews 2 (1): 21-22.

Proulx, G., A. Kolenosky, M. Badry, R. Drescher, K. Seidel, and P. Cole. 1994. Post-release movements of translocated fishers. Pages 197-203 in Martens, sables, and fishers: biology and conservation. Edited by S. W. Buskirk, A. S. Harestad, M. G. Raphael, and R. A. Powell. Cornell University Press, Ithaca, New York, USA.

Proulx, G., K. B. Aubry, J. Birks, S. W. Buskirk, C. Fortin, H. C. Frost, W. B. Krohn, L. Mayo, V. Monakhov, D. Payer, M. Saeki, M. Santos-Reis, R. Weir, and W. J. Zielinski. 2004. World distribution and status of the genus Martes in 2000. Pages 21-76 in Martens and fisher (Martes) in human-altered landscapes: an international perspective. Edited by D. J. Harrison, A. K. Fuller, and G. Proulx. Springer, New York, New York, USA.

Raine, R. M. 1983. Winter habitat use and response to snow cover of fisher (Martes pennanti) and marten (Martes americana) in southeastern Manitoba. Canadian Journal of Zoology 61: 25-34.

Rezendes, P. 1992. Tracking and the art of seeing. Camden House Publishing, Inc., Charlotte, Vermont, USA.

Received 21 April 2009

Accepted 15 April 2010 